\title{
Constraints Perceived by Dairy Farmers in Access and Management of Good Dairy Farming Practices
}

\author{
Tegdeep Singh Brar, Y. S. Jadoun", R. Kasrija, Parminder Singh and Bharti Deshmukh \\ Department of Veterinary \& Animal Husbandry Extension Education, Guru Angad Dev \\ Veterinary and Animal Sciences University (GADVASU), Ludhiana, Punjab, India \\ *Corresponding author
}

\begin{tabular}{l} 
K e y w o r d s \\
$\begin{array}{l}\text { Constraints, Dairy } \\
\text { farmers, Dairy } \\
\text { farming practices, } \\
\text { Agro-climatic zones }\end{array}$ \\
\hline Article Info \\
$\begin{array}{l}\text { Accepted: } \\
12 \text { October } 2020 \\
\text { Available Online: } \\
\text { 10 November } 2020\end{array}$ \\
\hline
\end{tabular}

\section{A B S T R A C T}

\section{Introduction}

Dairying and agriculture are bound together by a set of reciprocal input-output relations and among all the livestock ventures dairying

is the most prehistoric occupation established
The present study was conducted in two agro-climatic zones; Central plain zone (CPZ) and Western plain zone (WPZ) of Punjab having maximum number of dairy animals according to $20^{\text {th }}$ livestock census. The data were collected by using well structured interview schedule from 300 dairy farmers of CPZ and WPZ. Garrett's ranking technique was used to prioritize the different sets of constraints in terms of their mean score. The study revealed that "lack of training institute in the research locale (63.60)", lack of knowledge about schemes of A.H department (59.64) and "absence of milk testing facilities in study area (57.00)" were the major infrastructural constraints in terms of severity. Under technical constraints, "lack of knowledge about value addition of milk and milk byproducts (63.97)", "lack of knowledge about scientific housing practices (57.82)" and "lack of regular technical guidance facilities from experts (57.49)" were the major constraints. "Lack of credit facilities (62.21)", "high cost land (57.90)" and "high cost of feed and fodder (53.50)" were the severe economic constraints as perceived by dairy farmers. Under marketing constraints "difficulty in marketing of milk and milk products (60.03)", "lack of knowledge about marketing strategies (57.94)" and "distress sale due to perishable nature of milk and milk products (54.90)" were major constraints in terms of their severity. "Lack of know about various mobile applications related to scientific dairy farm practices (62.84)", "very few information of livestock management in daily newspaper/daily samachar (59.67"); "ambulatory service facility is not available in the area (56.52)" and "not getting the real information about scheme/programs at field level" (53.70) were major communicational constraints as perceived by dairy farmers. Hence, there is a need to remove these constraints on priority basis so that farmers can run their dairy enterprise in a smooth and better ways. in the rural setting of our country. Dairy sector contributes significantly in spawning employment opportunities and supplementing the income of small and marginal farmers. In recent years, the dairy sector has emerged as a most significant source of rural employment 
and income in the country. Dairy development has important role not only in generating employment and augmenting livelihood opportunities of rural people but also improving the nutritional security of the people.

India has largest livestock population in the world i.e., 535.78 million which constitute 192.49 million cattle, 109.85 million buffalos whereas total livestock population of Punjab is69.92 lac, out of which cattle population is 25.31 lacs and Buffaloes population is 40.15 lacs (Livestock Census 2020). India ranks first in milk production with a production level of 187.70 million tones milk during the year 2018-19 (Anonymous, 2019). The average milk yield in Punjab increased by 50.14 per cent between years 2012 and 2019 . The state now has the highest per capita milk availability in the country at 1,181 gram per day against the national average of 374 gram (Livestock Census, 2020).

In spite of the remarkable growth in milk production during the past few decades, productivity of dairy animals continues to remain very low and dairy farmers face various infrastructural, technical, economic, marketing and communicational constraints which are a major concern hindering further development of dairy industry. Proper identification of major constraints faced by dairy farmers the production \& productivity of dairy animal can be enhanced in a sustainable manner. Hence, the present study was carried out with an objective to explore various constraints perceived by dairy farmers in access \& management of good dairy farming practices (GDFPs).

\section{Materials and Methods}

\section{Selection and description of study area}

The present study was conducted in two agroclimatic zones; Central plain zone (CPZ) and
Western plain zone (WPZ) of Punjab. From CPZ; Ludhiana and Sangrur district and from WPZ; Tarn Taran and Ferozepur were selected purposively based on the maximum number of dairy animals, well developed infrastructure for dairy development and availability of potential dairy farmers in the respective zone. From each district 3 blocks were selected and out of 4 selected districts total 12 blocks were identified randomly and from each block cluster of 4 villages were selected. Potential dairy farmers in these village clusters were identified with help of veterinary officer's, extension officers and key informants \& representative sample of 25 farmers was randomly selected from four villages in each block giving a total sample size of 300 respondents for the study.

To analyze various constraints faced by dairy farmers, a structured interview schedule was developed under sub-heads namely; infrastructural, technical, economic marketing and communicational constraints. The data were collected by face to face interview using pre-tested structured schedule. Garrett's ranking technique was used to prioritize the different sets of constraints in terms of their mean score.

According to Garrett's ranking technique, the respondents were asked to enumerate and assign ranks to different constraints, which were used for prioritization of constrains. Order of merit as given by the respondents was converted into rank, by using the following formula:

Percent position $=\frac{100\left(\mathrm{R}_{\mathrm{ij}}-0.50\right)}{\left(\mathrm{N}_{\mathrm{j}}\right)}$

Where, $\mathrm{Rij}=$ Rank given for ith problems by jth individual.

$\mathrm{Nj}=$ number of problems ranked by the $\mathrm{jth}$ individual. 
The percent position of each rank was then converted into scores, by referring to the table, as given by Garrett. The scores of individual respondents for a particular problem were added and divided by the total number of respondents. The mean scores for all the constraints were arranged in descending order and thus, rank were assigned to prioritize the constraints.

\section{Results and Discussion}

A study of this nature would be incomplete, if the constraints were not identified. The literary meaning of "constraints" is the quality or state of being checked, restricted or compelled to avoid or perform some action. According to this study we can also define constraints as all those factors, which hinder the process of adoption and effective implementation of the good dairy farming practices (GDFPs) as perceived by the dairy farmers. The important constraints as faced by the respondents were ranked and discussed under the categories of infrastructural, technical, economic, marketing and communicational constraints. These constraints were analyzed and ranked with the help of Garret's ranking technique.

\section{Infrastructural constraints}

The data presented in Table 1 and Fig. 1, revealed that under infrastructural constraints "lack of training institute in research locale" (mean score: 63.60), "lack of knowledge about schemes of A.H department" (mean score: 59.64) and "absence of milk testing facilities in study area" (mean score: 57.00) were perceived as more severe and ranked $1^{\text {st }}$, $2^{\text {nd }}$ and $3^{\text {rd }}$.

These results were in line with findings of Seth et al., (2004) and Jeenger (2010) who reported that majority of the respondents had not taken training in dairy farming. It may be due to fact that lack of training organizations in the study area or located in urban area and semi urban area.

The other constraints such as "nonavailability of advanced dairy equipment's in the research locale " (Mean score: 56.40), "cost of veterinary medicine is very high" (Mean score: 55.31), "cost of veterinary medicine is very high (Mean score: 55.31), "lack of storage and preservation facility of milk and milk by-products" (Mean score: 49.43), "lack of space for modern dairy farm" (Mean score: 49.02), "facilities of veterinary services" (Mean score: 44.65) and "lack of water resources at farm for routine farm operations" (Mean score: 42.20) were ranked $4^{\text {th }}, 5^{\text {th }}, 6^{\text {th }}, 7^{\text {th }}, 8^{\text {th }}$ and $9^{\text {th }}$, respectively. These findings are in line with the findings of Nachimuthu (2002).

From the above findings it can be concluded that lack of training institute in the research locale, lack of knowledge about schemes of A.H department and absence of milk testing facilities in study area were highlighted a major constraints. Therefore there is a need to provide the basic infrastructural facilities such as; availability of training institute, dairy equipment's facilities, milk testing facilities, milk storage and preservation facilities, disease diagnostic facilities to the dairy farmers in their area so that they can run their dairy enterprise in a smooth and better ways.

\section{Technical constraints}

The results presented in the table 2 and Fig. 2, revealed that, "lack of knowledge about value addition of milk and milk by-products" (mean score: 63.97)" was perceived as most important constraint and ranked first. "Lack of knowledge about scientific housing practices" (mean score: 57.82); and "lack of regular technical guidance facilities from experts" (mean score: 57.49); were ranked 
second and third most important constraints faced by dairy farmers.

The other constraints includes, "lack knowledge about clean milk production" (mean score: 55.82); "lack of knowledge about feeding of balanced ration to the animals" (mean score: 53.61), "lack knowledge about deworming and vaccination schedule" (mean score: 50.64), "unavailability of Artificial Insemination (A.I) centres in the study area" (mean score: 50.64), and "lack of technical 'know how' about management of dairy units" (mean score: 50.64), were ranked as $4^{\text {th }}, 5^{\text {th }}, 6^{\text {th }}, 7^{\text {th }}$ and $8^{\text {th }}$ respectively, on the basis of their mean score among the various technical constraints. These constraints may be attributed because lack of proper technical guidance well in time, low mass media exposure and low extension contact by the respondents, which is in agreement with the findings of Singh et al., (2004) and Tiwari et al., (2003).

These constraints may be sorted out by organizing animal welfare camps, awareness camps, regular technical guidance about scientific breeding, feeding, healthcare and management practices through telephone helpline, radio, T.V. and various other social media tools.

Table.1 Infrastructural constraints

\begin{tabular}{|l|l|c|c|}
\hline Sr. No. & Infrastructural constraints & $\begin{array}{c}\text { Mean } \\
\text { score }\end{array}$ & Rank \\
\hline 1 & $\begin{array}{l}\text { Non availability of advanced dairy equipment's in the research } \\
\text { locale }\end{array}$ & 56.40 & IV \\
\hline 2. & Lack of space for modern dairy farm & 49.02 & VII \\
\hline 3. & Facility of veterinary services & 44.65 & VIII \\
\hline 4 & Lack of training institute in the research locale & 63.60 & I \\
\hline 5 & Cost of veterinary medicine is very high & 55.31 & V \\
\hline 6 & Absence of milk testing facilities in study area & 57.00 & III \\
\hline 7 & Lack of water resources at farm for routine operations & 42.20 & IX \\
\hline 8 & $\begin{array}{l}\text { Lack of storage and preservation facility of milk and milk by- } \\
\text { products }\end{array}$ & 49.43 & VI \\
\hline 9 & Lack of knowledge about schemes of A.H department & 59.64 & II \\
\hline
\end{tabular}

Table.2 Technical constraints

\begin{tabular}{|c|c|c|c|}
\hline $\begin{array}{l}\text { Sr. } \\
\text { No. }\end{array}$ & Technical Constraints & $\begin{array}{l}\text { Mean } \\
\text { score }\end{array}$ & Rank \\
\hline 1 & Lack of technical 'know how' about management of dairy units & 45.62 & VIII \\
\hline 2 & Lack of regular technical guidance facilities from experts & 57.49 & III \\
\hline 3 & Lack of knowledge about feeding of balanced ration to the animals & 53.61 & $\mathrm{~V}$ \\
\hline 4 & Lack of knowledge about scientific housing practices & 57.82 & II \\
\hline 5 & Lack knowledge about clean milk production & 55.82 & IV \\
\hline 6 & Lack knowledge about deworming and vaccination schedule & 50.64 & VI \\
\hline 7 & $\begin{array}{l}\text { Lack of knowledge about value addition of milk and milk by- } \\
\text { products }\end{array}$ & 63.97 & I \\
\hline 8 & $\begin{array}{l}\text { Unavailability of Artificial Insemination (A.I) centres in the study } \\
\text { area }\end{array}$ & 47.00 & VII \\
\hline
\end{tabular}


Table.3 Economic constraints

\begin{tabular}{|l|l|c|c|}
\hline $\begin{array}{l}\text { Sr. } \\
\text { No. }\end{array}$ & Economic Constraints & $\begin{array}{c}\text { Mean } \\
\text { score }\end{array}$ & Rank \\
\hline 1 & Lack of credit facilities & 62.21 & I \\
\hline 2 & High cost land & 57.90 & II \\
\hline 3 & High cost of feed and fodder & 53.50 & III \\
\hline 4 & High cost elite breeds for dairy animals & 52.30 & IV \\
\hline 5 & Low economic gain from dairy enterprise & 50.70 & VI \\
\hline 6 & High cost of transportation & 48.50 & VII \\
\hline 7 & $\begin{array}{l}\text { Limited subsidies by government for starting of dairy } \\
\text { enterprise }\end{array}$ & 50.93 & V \\
\hline
\end{tabular}

Table.4 Marketing constraints perceived by dairy farmers

\begin{tabular}{|l|l|c|c|}
\hline $\begin{array}{l}\text { Sr. } \\
\text { No. }\end{array}$ & Marketing Constraints & $\begin{array}{l}\text { Mean } \\
\text { score }\end{array}$ & Rank \\
\hline 1 & Difficulty in marketing of milk and milk products & 60.03 & I \\
\hline 2 & Lack of knowledge about marketing strategies & 57.94 & II \\
\hline 3 & $\begin{array}{l}\text { Less knowledge about marketing channel of milk and milk } \\
\text { products }\end{array}$ & 52.86 & IV \\
\hline 4 & $\begin{array}{l}\text { Interferences of middle man in supply chain management } \\
\text { products }\end{array}$ & 51.05 & V \\
\hline 5 & $\begin{array}{l}\text { Distress sale due to perishable nature of milk and milk } \\
\text { product }\end{array}$ & III \\
\hline
\end{tabular}

Table.5 Communicational constraints

\begin{tabular}{|l|l|c|c|}
\hline $\begin{array}{l}\text { Sr. } \\
\text { No. }\end{array}$ & Communicational Constraints & $\begin{array}{l}\text { Mean } \\
\text { score }\end{array}$ & Rank \\
\hline 1 & Poor market information system & 48.52 & VI \\
\hline 2 & $\begin{array}{l}\text { Non-cooperative nature of progressive dairy farmers } \\
\text { Difficulty in approach to veterinary services }\end{array}$ & 44.34 & VII \\
\hline 3 & $\begin{array}{l}\text { Not getting the real time information about government } \\
\text { scheme/programs at field level. }\end{array}$ & 53.70 & VIII \\
\hline 4 & $\begin{array}{l}\text { Ambulatory service facility is not available in the area } \\
\text { Unavailability of livestock related literature }\end{array}$ & 56.52 & III \\
\hline 6 & $\begin{array}{l}\text { Very few information of livestock management daily } \\
\text { newspaper/daily samachar }\end{array}$ & 59.67 & II \\
\hline 8 & $\begin{array}{l}\text { Lack of knowledge about various mobile applications } \\
\text { related to scientific dairy farming practices }\end{array}$ & 62.84 & I \\
\hline 9 & \begin{tabular}{l} 
Internet network problem in the study area \\
\hline
\end{tabular} & 35.44 & IX \\
\hline
\end{tabular}


Fig.1 Infrastructural constraints faced by dairy farmers

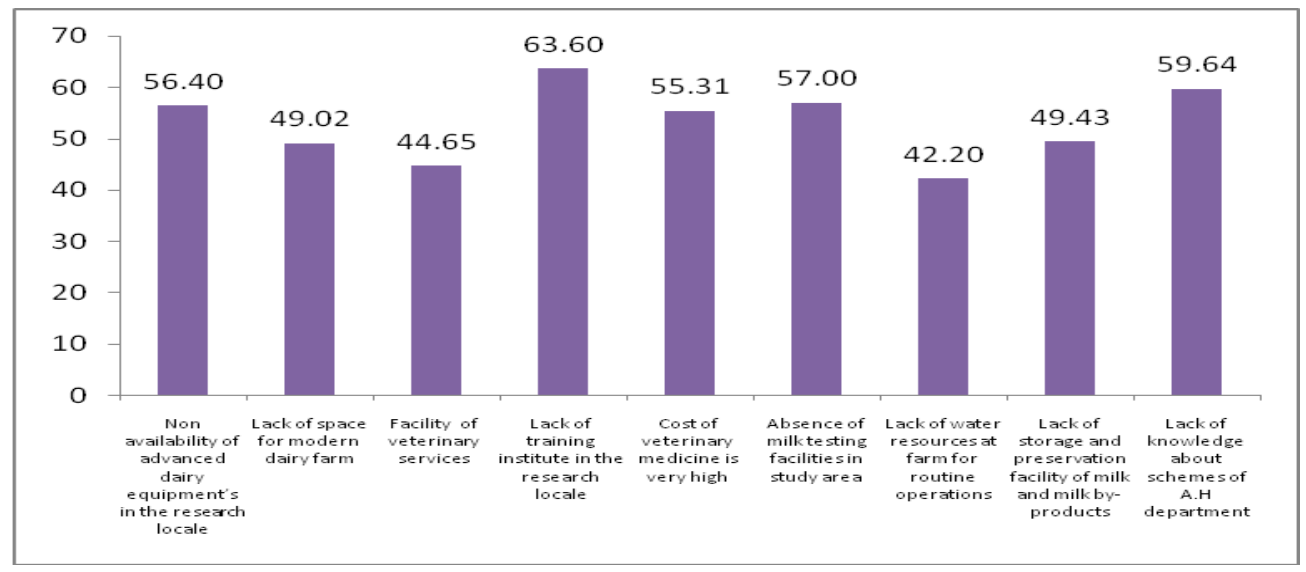

Fig.2 Technical constraints perceived by dairy farmers

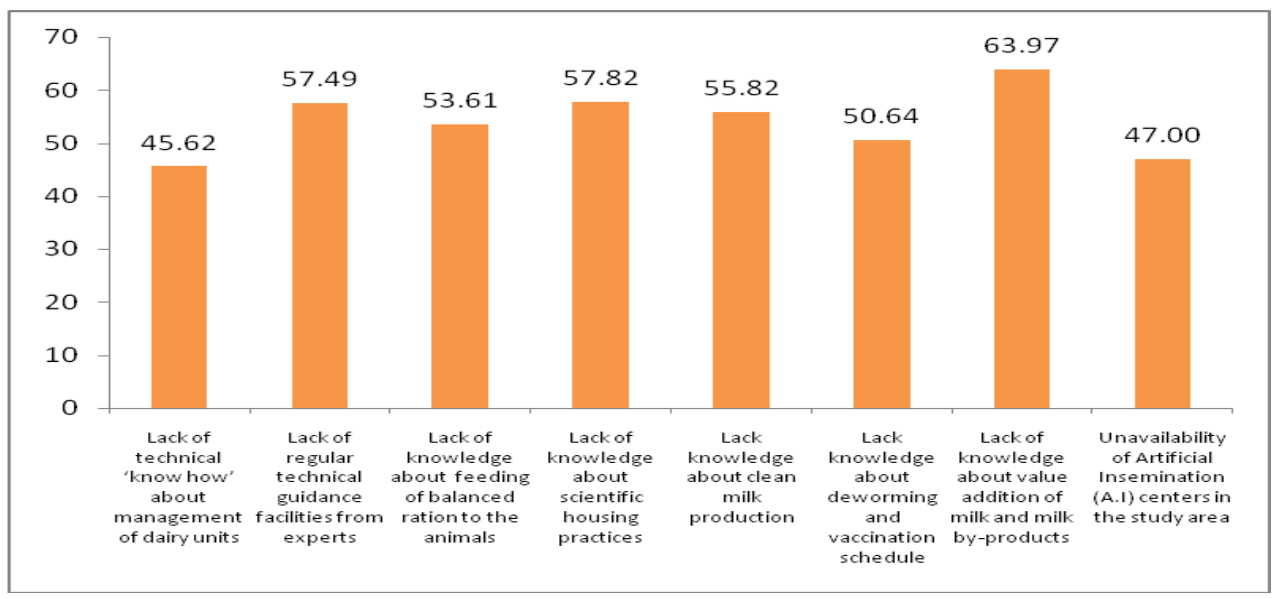

Fig.3 Economic constraints perceived by dairy farmers

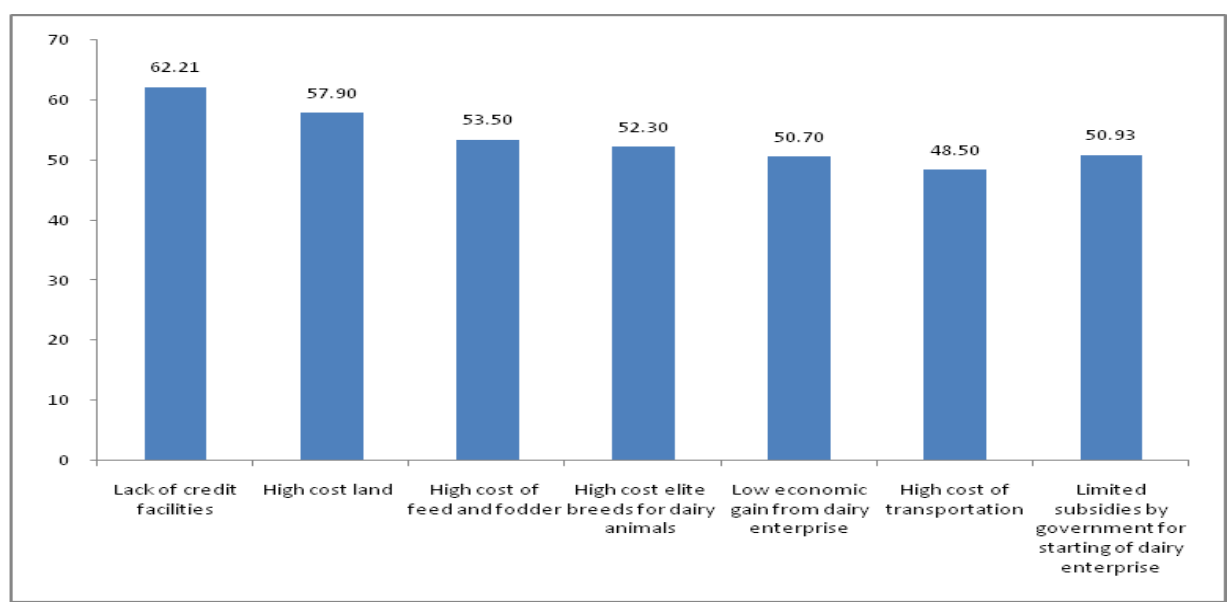


Fig.4 Marketing constraints perceived by dairy farmers

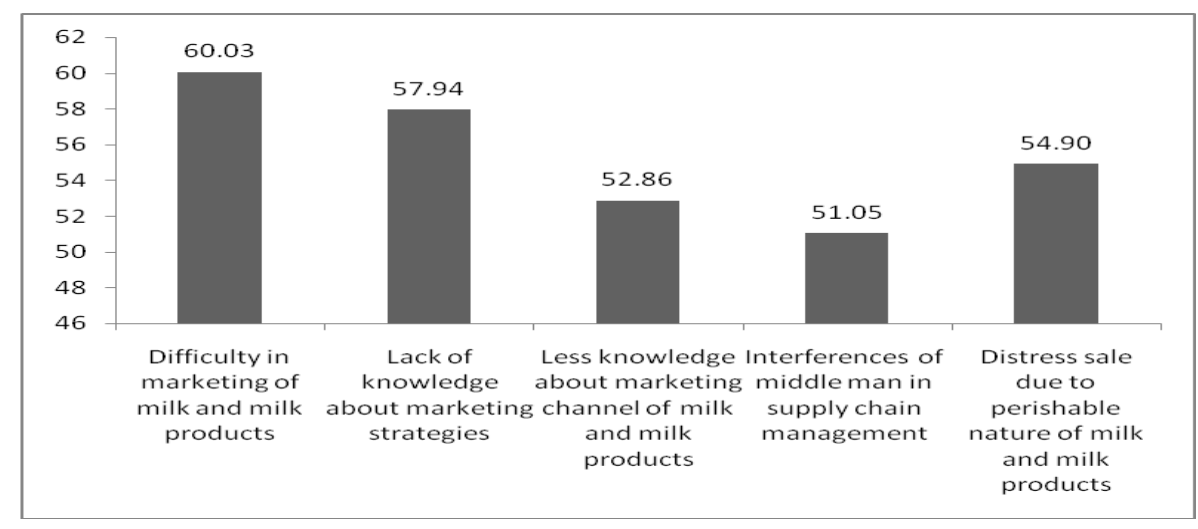

Fig.5 Communication constraints perceived by dairy farmers

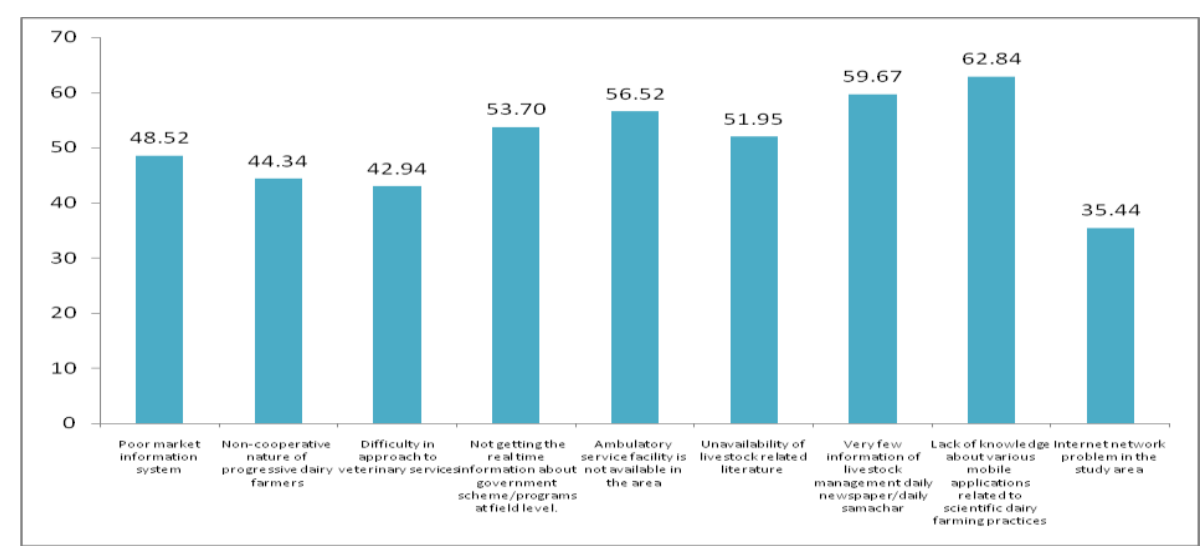

\section{Economic constraints}

The data presented in table 3, Fig. 3 revealed that under economic constraints "lack of credit facilities" (mean score: 62.21) was perceived as most severe constraint. Similar result was depicted by Rao et al., (2013) and Uday et al., (2013) who reported lack of credit facilities as the major constraints in dairy farming.

The other constraints such as "high cost land" (Mean score: 57.90) and "high cost of feed and fodder" (Mean score: 53.50) were always an issue for farmers when they want to start a dairy enterprise were perceived as $3^{\text {rd }}$ and $4^{\text {th }}$ most important constraints. The other constraints such as "high cost of elite breeds for dairy animals" (Mean score: 52.30), "limited subsidies by government for starting of dairy enterprise" (Mean score: 50.93), "low economic gain from dairy enterprise" (mean score: 50.70) and "high cost of transportation" (mean score: 48.50) were ranked 4 th, 5 th, $6^{\text {th }}$ and $7^{\text {th }}$ respectively on the basis of their severity on the basis of their mean score. These findings are in line with Sarker and Ghosh (2010) and Minhaj et al., (2019), who reported that high cost of feed and or mineral mixture was perceived as most serious constraint followed by high cost of fodder and non availability of pasture.

\section{Marketing constraints}

Market plays an important role in diffusion and adoption of new technology. From Table 4 and Fig. 4, it is indicated that "difficulty in 
marketing of milk and milk products" (mean score: 60.03) was perceived as most serious constraint by the dairy farmers. The possible reasons for difficulty in marketing of milk and milk by-products might be due to high competition from major units and consumer's preference to quality milk, similar result was in line with the findings of Singh et al., (2019). Hence it is suggested that there should be improved marketing system, so that milk producers will not face difficulty in marketing of milk and milk products.

The other constraints were "lack of knowledge about marketing strategies" (mean score: 57.94); was found to be second most serious constraints "Distress sale due to perishable nature of milk and milk products (mean score: 54.9) has been found to be the second and third most serious constraints followed by "less knowledge about marketing channel of milk and milk products" (mean score: 52.86) and "interferences of middle man in supply chain management" (mean score: 51.05 ) were ranked $4^{\text {th }}$ and $5^{\text {th }}$ constraints, respectively on the basis of their mean score.

\section{Communicational constraints}

The data presented in table 5, Fig. 5 indicated that among communicational constraints "lack of know about various mobile applications related to scientific dairy farm practices" (mean score: 62.84) was the most serious constraint faced by the dairy farmers.

The other constraints were "very few information of livestock management in daily newspaper/daily samachar" (mean score: 59.67); "ambulatory service facility is not available in the area" (mean score: 56.52); "Not getting the real information about scheme/programs at field level" (mean score: 53.70); "unavailability of livestock related magazine" (mean score: 51.95), poor market information system (mean score: 48.52), noncooperative nature of progressive dairy farmers (mean score: 44.34), difficulty in approach to veterinary services (mean score: 42.94) and internet network problem in the study area (mean score: 35.44) were faced as second, third, fourth, fifth, sixth, seventh, eighth and ninth important constraints, respectively by the dairy farmers.

It could be concluded from the above study that for sustainability of dairy farming enterprise there is a need to establish proper training institutes in the rural areas for capacity building and refreshing their knowledge base of dairy farmers on regular basis and need to provide basic input facilities, disease diagnostic facilities and milk storage and preservation facilities to the dairy farmers in their locale so that they can run their dairy enterprise in a smooth and better way. There is a dire need of improved marketing system so that milk producers will not face difficulty in marketing of milk and milk products. In nutshell, constraints should be minimized immediately for the betterment and improving the socio-economic status of dairy farmers.

\section{Acknowledgement}

Vice chancellor, Guru Angad Dev Veterinary and Animal Sciences University, Ludhiana, Punjab for providing all necessary facilities and in connection with this research work. Support form veterinary officers, extension officers, veterinary inspectors and key stakeholders is duly acknowledged.

\section{References}

20th Livestock Census (2019). Department of Animal Husbandry, Dairying \& Fisheries Ministry of Agriculture \& Farmers Welfare Government of India, New Delhi. 
Anonymous 2019. Economic Survey 201819. The Economic Times, Archived July 04, 2019

Jeengar H K. 2010. Socio-economic impact of district poverty initiative project (DPIP) on dairy farmers in Rajasthan. Ph.D. Thesis, N.D.R.I., Karnal.

Minhaj S U, Shafkat A K, Rayees A B, Bharat B, Farzana C and Adil M K. 2019. Constraints Perceived by Dairy Farmers in the Adoption of Improved Animal Husbandry Practices in Doda District. International Journal of Livestock Research 9(2): 319-326.

Nachimuthu, K. 2002. Socio-economic and technological impact of animal husbandry programs in Pondichery. Ph.D. Thesis (Unpublished). NDRI Deemed University, Karnal, Haryana, India.

Rao T K S, Patel N B, Fulsoundar A B and Gamit V K. 2013. Constraints limiting the livestock productivity of tribal community in high rain coastal region of India. Research

Sarker D and Ghosh B. 2010. Constraints of milk production: A study on cooperative and non-cooperative dairy farms in West Bengal. Agricultural Economics Research Review 23: 303-
314.

Seth P. 2004. Problems and prospects of dairy cooperatives in Jharkhand. M.V.Sc. Thesis, Birsa Agricultural University, Ranchi, India.

Singh P R, Singh M and Jaiswal R S. 2004. Constraints and strategies in rural livestock farming in Almora district of hilly Uttranchal. Indian J. Animal Research, 38 (2): 91-96.

Singh P, Rampal V K, Sharma K and Dhaliwal N K. 2019. Constraints analysis of dairy farmers in Malwa Region of Punjab. Journal of Community Mobilisation and Sustainable Development 14(3): 384388.

Tiwari R K, Bisen J P and Sharma P N. 2003. A study on constraints and suggestions regarding adoption of improved animal husbandry practices in Chhattisgarh Plains". Indian Research Journal of Extension Education, 3 (1): 22-29.

Uday O P, Shahaji D S, Deshmukh and Munder B S. 2013. Constraint faced by village leaders in dairy development activities. Journal of Communication Mobile and Sustainable and Development 8 (2): 257-261.

\section{How to cite this article:}

Tegdeep Singh Brar, Y. S. Jadoun, R. Kasrija, Parminder Singh and Bharti Deshmukh. 2020. Constraints Perceived by Dairy Farmers in Access and Management of Good Dairy Farming Practices. Int.J.Curr.Microbiol.App.Sci. 9(11): 1600-1608.

doi: https://doi.org/10.20546/ijcmas.2020.911.190 